\title{
Identification of saprahan values as formers of gifted students empathy in high school students in pontianak
}

\author{
Hastiani $^{1}$, Rezki Hariko ${ }^{2^{*}}$ \\ ${ }^{1}$ IKIP PGRI Pontianak, Pontianak, Indonesia, ${ }^{2}$ Universitas Negeri Padang, Padang, Indonesia \\ *Corresponding author, e-mail: hariko@konselor.org
}

\begin{abstract}
Gifted students tend to have too perfectionistic social skills, want others to be in accordance with the desired logic, comfortable interacting with students with homogeneous characteristics. This tendency can be modified by school counselors through the integration of the values of Saprahan local wisdom into guidance and counseling services. The values contained in Saprahan are used as the formation of students' empathy skills. Thus, gifted students have concern for other colleagues, can interact well with students of various characters, accept the shortcomings of other friends, embrace and help other friends, be polite in communicating, and not demean other friends.
\end{abstract}

Keywords: Empathy, Saprahan, GiftedStudent.

How to Cite: Hasriani, H., Hariko, R. (2019). Identification of saprahan values as formers of gifted students empathy in high school students in pontianak. International Journal of Research in Counseling and Education, 3 (1): pp. 15-21, DOI: https://doi.org/10.24036/0058za0002

This is an open access article distributed under the Creative Commons 4.0 Attribution License, which permits unrestricted use, distribution, and reproduction in any medium, provided the original work is properly cited. @2018 by author.

\section{Introduction}

The characteristics of students with above-average ability should receive special services in educational programs. The aim is that the education process can optimally channel and fulfil the needs in accordance of the ability that is owned by students. One characteristic of students with above-average ability is to experience development faster than other students. A group of students with abilities as mentioned above are known as gifted students. Santrock (Pranungsari, 2012)defines gifted children as children who have high intelligence (IQ = 130 and more) and or have superior talent in certain fields.According to the giftedness theory proposed by Renzulli (Sugiarti \& Suhariadi, 2015) some characteristics of students who can be categorized as a gifted student, such as: individuals who have an IQ > 130 on a Wechler Scale, have commitment or attachment to the task and have high creativity. Furthermore, based on a review of aspects of intelligence, according to Wechsler (Pranungsari, 2012)IQ of gifted children is above the score of 115; 115129 are middle gifted, 130-144 are moderate gifted, and 145 and more are highly gifted. Related to this, according to Vialle, Heaven \& Ciarrochi (Zeidner, 2017) gifted students have a challenge of adjusting their self toward social emotional conditions in a particular domain, for instance isolation from peers.

The law of education Indonesia article 5 paragraph 4 explained that every citizen in this case is a student who has the potential for intelligence and special talents entitled to receive special education (Indonesia, 2003). Then, in article 32 paragraph 1 explained that special education is type of educations for students who have a level of difficulty in following the learning process due to physical, emotional, social and/or special potential intelligence or talents. Special education as conveyed in the law intends to improve the potential and excellence of students as their real achievements that are in accordance with their features. Furthermore, students can explore their special abilities without neglecting the developments of intellectual, emotional and spiritual intelligence aspects.

Although the implementation of education of gifted students has been guaranteed by the law, the application of special programs on this domain in the field does not run comprehensively. As the result, special classes through new enrichment managed to focus only on the development of students' academic intelligence. Some of the negative impacts that arise are even more surprising. Student $s$ learning time which is very tight caused students having less additional time to do the interaction process into a wider social situation. 
Similar to some regions in Indonesia, the implementation of special education services for gifted students has been held at some of senior high schools in Pontianak City. The implementation of this service begins with the selection process by utilizing the help of psychological testing institutions to measure intelligence, confidence, strength and determination toward the task, struggling power in completing tasks, and creativity performance when performing skills in class. The next requirement is originated from the results of national examinations on particular subjects that are set at certain standards. Parental contributions in the student selection process are actualized in the form permission letters approval to allow their children joining special class for gifted students.

The form of special education services for gifted students is materialized through enrichment programs, that is, increasing learning time - from morning to evening. Teachers who taught in special class also taught in regular class so it made no difference between special class and regular class teacher. On the other hand, the social characteristics of gifted students were contrary to the special abilities they owned. According to Clikermen (Sugiarti \& Suhariadi, 2015) gifted students are groups of students who have abundant energy (over excitabilities), they easily get bored when they are faced with subject matter or information that has been known previously and feel that what is gained is not challenging for them. Those conditions enable gifted students to show socially unproductive attitudes, such as not paying attention, not caring for others, not doing other things that attract their attention and meeting their challenges, disturbing friends, quickly criticizing but overwhelmed by their perfectionist characteristic just make them difficult to accept criticism from others.

Gifted students enjoy to gather only with similar characteristics individuals as them. Their development that is considered too fast regarding with understanding creates inconvenience in heterogeneous conditions, individualistic and competent although in a group, being closed, being unhappy to share, being afraid of someone will compete their achievements. The social life of gifted students tends to be in a dilemmatic situation toward the inaccuracies of the speciality they possess, the moral burden either their personal or people expectations.

To deal with social characteristic conditions, it is necessary to offer a help for gifted students to have a concern for friends, teachers as well as in wider social environment. Gifted students are expected to show openness which is characterized by having the ability to get along, can accept differences with regular or being openness students to individuals who are not considered gifted students. Then, gifted students are also expected to have a sense of togetherness which is characterized by feeling as freedom in living their life as a student who needs friendship with other friends and has politeness norm. Gifted students are expected to be able to respect others by not doing actions that will reduce the sympathy of others towards their speciality. Related to this, gifted students need empathy skills.

Related to the elaborated discussion above, the writer raises the idea about the cultural value of the Pontianak Malay community known as Saprahan. The value contained in Saprahan contains the message of custom and morals as a guide in behaving. Adapun nilai-nilai yang terangkum dalam budaya Saprahan meliputi: caring (senasep sepenanggungan), togetherness (seadat sepusaka sepucuk setali darah), politeness (bercakap bersetinah berunding bersetabik), and openness (seanak sekemanakan).Saprahan values are intended to stimulate the formation of gifted students' empathy. The idea of using Saprahan values will be implemented by the school counselor through the implementation of guidance and counseling services in the field of personal-social guidance.

\section{Empathy of Gifted Students}

Gifted students are groups with different variety, and come from different socioeconomic and ethnic backgrounds. The label of gifted students is not only related to their ability but also covers a broader spectrum, not only related to academic intelligence that is superior or above average but also about how the ways to manage emotions, social abilities and interactions to others. Research by Schwean, Saklofske, Widdifield-Konkin, Parker, \& Kloosterman (2006) identifies a number of intellectual characteristics that show that in some intellectual gifted children often experience problems, as well as a social emotional challenge this is due to differences between cognitive abilities and psychosocial abilities. There is no evidence that gifted children are better than other children, even though teachers in schools apply specific strategies to teach them (Robinson \& Clinkenbeard, 2008). According to Silverman \& Vantel (Wahab, 2010) the socialemotional problems of gifted students are characterized by several characteristics, such as confused about the meaning of gifted; feel inappropriate with speciality, expectations of parents and society; self-criticism and lack of understanding both their self and others as well as the hostility of others toward gifted children. The tendency of gifted students who spend their time in class during break time, doing assignments and playing with other gifted students, and comfortably playing only with gifted groups of students will certainly 
have a negative impact on their social development. Furthermore, according toBakar (2016) related to emotional instability reflected through behaviour including sensitivity, feelings of isolation and tendency of perfectionism from unique personal characteristics and environmental factors. In general, gifted students differ from other normal students in several aspects of physical, psychomotor, emotional, intellectual and social domain development. Gifted students experience emotional stress caused by social isolation, sometimes gifted students feel social isolation because of their own intellectual abilities.

At the stage of development of making friends and building friendship, it is essential for students to have a positive relationship with peers. Healthy interaction with peers will help to solve conflicts and maintain relationships. Other peers and adults will provide a help to build social development, to develop selfawareness and social care which are the main aspects of empathy. According to Goleman (1977) individuals who have the ability to empathize are better able to accept other people's perspectives (openness), able to improve empathy and sensitivity to other people's feelings (togetherness, caring and self-awareness), and able to listen to others (politeness, caring and understanding).

By the existence of empathy skills, gifted students can live together in a social environment. Empathy skills possessed by gifted students enable them to survive in heterogeneous groups, to show social caring attitudes with moral standards that can be expressed socially culturally and that are allowed in society. Thus, gifted students transform into individuals who develop in psycho-sociocultural way. In this case, according to Rogers (Kazanjian \& Choi, 2016) empathy describes the situation when someone personally and fully exists in their own world of thoughts and feelings, and in other conditions, can explain and differentiate not only the deepest part but also about what they know during their consciousness.

Confirmed from Goleman, (Bakar, Ishak, \& Abidin, 2014) in terms of emotional intelligence, empathy skills can be identified from one's ability to understand others, help others develop the potential of others, provide services to others, work with different groups of individuals, be aware of the dynamics develop around the environment and continuously show caring attitude toward others. Gifted students who own empathy tend not to force their desires on others to be exactly as they want to, capable to accept any judgment about themselves as well as to feel wholeheartedly the conditions that occur in their social environment so that they feel what others desire and need that then they can help them with their speciality, gifted students will be more aware of the dynamics of environment.

\section{Personal-Social Guidance Based on Saprahan Value}

Socio-culturally, the province of West Kalimantan consists of a pluralistic society inhabited by two main indigenous ethnics known as Malays and Dayaks. The ethnic of Dayaks generally lives at inland areas, while the Malays are at coastal or urban areas (Batubara, 2017). Prasojo (King, Ibrahim, \& Hassan, 2017) explains that one of the characteristics of Malay people in province of West Kalimantan is to uphold a sense of kinship and togetherness. Those are the main source of a solidarity among smaller ethnics in the Malay society. One of the local culture values that is still preserved by the Malay society until now is Saprahan. (Muzayanah, 2017) confirms that Saprahan is a tradition of Malay people to serve guests in form of a process of eating together to build togetherness, openness, caring and politeness. Kinship and togetherness that are highly upheld makes the Malay community powerful, not easily to rip apart by external factors that are the results of life challenge and time changing.

Cited from Arpan (2014), philosophically the values contained in Saprahan, namely: caring (senasep sepenanggungan), togetherness (seadat sepusaka sepucuk setali darah), politeness (bercakap bersetinah berunding bersetabik), and openness (seanak sekemanakan). The Malay society interprets the moral message in the Saprahan tradition which symbolizes a sense of togetherness and mutual cooperation with the phrase "berat sama dipikul ringan sama di jinjing, berdiri sama tinggi duduk sama rendah". As one form of local wisdom, Saprahan is still applied at various events, such as a moments before the wedding, Robo robo ceremony - commemorating the death of Opu Daeng Menambon, the king of Mempawah, Beroah event sending the prayers of tahlil by Malay society in Malay villages, and the anniversary of the Pontianak city. Nowadays, Saprahan has been used as a material of muatan lokal (local content) lessons at the secondary school level in West Kalimantan Province which aims to introduce the young generation about local cultural heritage as the personal identity of Pontianak people.

The value of senaseb sepenanggungan, that is, to grow a sense of social responsibility to help each other, support each other, to remind others in daily life. The phrase that describes this value is called "adat senaseb sepenanggungan dalam sempet same berhimpet, dalam lapang same melenggang", which means that the characteristic of alive individual are able to feel the happiness of life in an atmosphere of helping each other, ease the burden of other people, either brothers or neighbours, even the general society, (Arpan, 2014; King et al., 2017)The value of caring in showing empathy skills might make gifted students able to notice their 
friends who are in needs, offer help and time to solve the difficulties that other students deal with, even though only a little help can be so meaningful for friends in need. Related to this, it is specifically emphasized to help each other into social life without considering the personal background of students whether they are not or gifted students.

A moral message that is embedded in a value of seadat sepusaka, sepucuk setali darah, is to make gifted students can maintain solidarity, togetherness and loyalty in their social life, embrace their friends with different characteristics, and uphold the values of marwah and tuah of dignity and respect in social life that become a foundation for fertilizing a sense of togetherness and mutual respect, (Arpan, 2014; King et al., 2017). By togetherness, gifted students feel strong and capable to survive in any obstacle of life as a part of social system. Togetherness is considered as binding chain that makes them not easily to be disunited from any obstacles that try to separate them. The value of togetherness is the spirit that gifted students must have so that they cannot be separated from their social life, isolate themselves in separated social groups- make friends only with their fellow gifted students - but to blend, to unite in social life.

The value of bercakap bersetinah berunding bersetabik gives moral messages for gifted students to be polite, not underestimate other friends - both from academic abilities and social background perspectives respect opinions and not force personal opinions, behave politely, respect others - either words, attitude or deed - be a person who is neat in behaving, virtuous, prioritizing the older, not saying harshly, and maintaining spoken language both in formal and non-formal situations, with friends and wider community (Arpan, 2014; King et al., 2017). The value of bercakap bersetinah berunding bersetabik is reflected in the phrase tande orang terpuji bercakap tadak mengeji, berkate tadak memfitnah, menyanggah tadak menyumpah . Gifted students who are empathetic with others and respect other people are described as students who have good morals.

The value of seanak sekemanakan contains a moral message that gifted students have to be able to be open, not discriminating individuals in terms of their social relationship, both in the school environment and society in general. Gifted students are expected to be selective in their relationship but not differentiate individuals based on non-gifted or gifted matter, flexible in relationships, accept each other's limitations and strengths, and have many friends. Competition in the aspect of achievement is used as a place to motivate themselves and as a way of adding new networks and knowledge. The value of seanak sekemanakan is further reflected in the phrase tangan erat membuat pekerjaan ringan berdiri setinggi bersama dudok serendah bersama . This expression has meaning of solidarity and wisdom.

In regard to Saprahan value as the formation of student s empathy, Indonesian government actively encourages the realization of education implementation that focuses on strengthening student $\mathrm{s}$ character education. This is illustrated by the emergence of Presidential Regulation (Indonesia, 2017). The regulation becomes the basis for the implementation of guidance and counseling programs, especially in the social and personal field to facilitate comprehensive development of gifted students through the formation of caring characters toward social issues. Additionally, regarding with the socio-emotional problems gifted students experienced, according to van Tessle-Baska (Zeidner \& Matthews, 2017) it is necessary to make efforts to develop social relation development skills in the wider social environment that enable gifted students to feel and find out the meaning of life in the togetherness climate.

Based on the study of saprahan values, it can be concluded that essentially, human beings are free in determining themselves. However, as free beings, humans must be responsible for their freedom. Furthermore, human beings as free social beings have the same degree before God as illustrated by the phrase dudok same rendah, berdiri same tinggi . Recognizing the unique and speciality possessed by gifted students who has personality that are not owned by other students, children in general, as a creature of God and realizes that their speciality is not including all aspects of development so that they are aware of the weaknesses they have to enable gifted students to think and decide how to overcome their weaknesses. To realize gifted students to choose alternative action and responsibility for choices, so that what their choices can eliminate their anxiety of weaknesses. To realize gifted students that they need other students, both nongifted and fellow gifted students to stick together expressing their potential and passing through weaknesses so that by togetherness, they can find the meaning of life. Self-awareness to understand other people with different characteristics than gifted students cannot continuously materialize their perfectionism that nongifted students will follow their intentions, with the care possessed by gifted students, there will be a sense of responsibility to help other students channel their potential and support each other, and gifted students along with their openness are able to blend into a wider social situation. Non-gifted students broadly can make gifted students aware of the meaning of life can be met when they are with others in a broad social situation, accepting and being accepted, through the role of guidance and counseling in the field of social personal guidance, gifted students are not only academically intelligent but also socially and culturally. 
An effort to integrate Saprahan values in harmony with the meaning of education as a process of cultural preservation, introducing and inheriting the value of local cultural wisdom in the school environment. The main activities of education that take place at schools should be able to support the national movement for the development of national character through culture. In line with this, according to Johnson \& Sandhu (2010) the implementation of guidance and counseling services that integrate elements of local cultural wisdom values have several characteristics, those are (1) making slight adjustments to traditional counseling that already exists by including cultural or religious material aimed at forming behaviour in accordance with cultural values or religious values, (2) adjusting the counseling approach with more dominant cultural elements in a local place or community, and (3) specifically adopting the main cultural elements of the local community to be used as a basis for the counseling implementation process.

Cultural competence is a product of generic cultural competencies and certain cultural competencies, both of which are important in each phase of psychotherapy (Lo \& Fung, 2003). Culturally competent counselors have achieved an accurate awareness of the cultural assumptions they have learned because these assumptions may be the same and/or different from the assumptions of culturally different clients. Culturally, they have understood meaningful facts and information that describe the cultural context of each client. Culturally competent counselors are able to act appropriately to help clients achieve positive results (Pedersen, 2002). According to Rosjidan (Wibowo \& Anjar, 2017)relevant cultural values serve as a source of learning for adolescents or clients in the counseling process including empathy or tolerance. This cultural value can be interpreted as sensitivity to and the ability to understand the feelings of others, the ability to care about the conditions of others and the environment, and the ability to foster life in togetherness. However, the ability of the counselor to explore and exploit cultural values in the counseling process becomes a very important factor for achieving understanding and strengthening the character of adolescents based on local cultural values.

The process of absorption and/or adoption of local wisdom values into the implementation of counseling has emerged a process that is also commonly referred to as indigenous counseling. Indigenous counseling means counseling that is rooted in a system of knowledge and practice of society, a place where individuals internalize their knowledge systems and behavior practices. In this context, multicultural counseling skills can be identified and/or associated with indigenous counseling skills. However, every culture can actually be drawn into the indigenous counseling process. This indigenous counseling will construct community views, in the counseling process, about humans and the universe. Indigenous counseling also shows their understanding of person, self, life goals, and values that are used as a foundation (Buggie, 1997).

In general, early counseling theories absorbed a lot of Western cultural values, which were designed and applied in the context of Western industrial society (Hariko \& Ifdil, 2017; Hwang, 2009; Pedersen, 2002). This condition certainly has become an obstacle and/or an obstacle if applied to non-Western culture, for example in Indonesian society. However, this reason certainly cannot be made a justification for the opinion that these theories cannot be utilized at all. In this case, innovation and creativity are needed so that these theories become more applicable by marrying them to the values of local wisdom that exist around prospective clients. One of the local cultural values that can be used in organizing counseling is Saprahan's local wisdom values. However, the counseling process rooted in "local-cultural values" does not mean ignoring counseling concepts that are universally applicable. The integration of the values of Saprahan into the implementation of guidance and counseling in schools is considered as a fairly effective breakthrough.

\section{Conclusion}

The explanations that the writer describes above give the message to counselor to provide a space in the development of aspects of social personal guidance by helping gifted students to deal with their personal conflicts in terms of their social emotional aspects, that is, their empathy skills. The characteristics of gifted students, such as individualists, excessive anxiety towards peers regarding with learning achievement which ultimately displays an act of preventing to share with others, boredom and impatience that dominates and finally makes them to be disrespect to others, looking for other ways that lead them to an unsympathetic attitude toward others. Distracting attention of considering other people and insisting their perfectionism to others can make other people don $\mathrm{t}$ understand their intentions.

Social personal guidance provided by covering the values of Saprahan as one of the local wisdoms of Malay people in Pontianak, the values found in local wisdom of Saprahan form gifted students' empathy skills through the awareness to have a sense of Caring value (Senaseb Sepenanggungan), Togetherness value (Seadat Sepusaka Sepucuk Blood Equivalent), Politeness value (Bercakap Bersetinah Berunding Bersetabik), Openness value (seanak sekemanakan). The local wisdom values of Saprahan is a culture-based guidance and counseling approach that can help to rise empathy skills, so gifted students will capable to sense other 
students' intentions both from non-gifted and gifted students, social care, compassion, not discriminating in socializing, capable to fertilize togetherness either in social or financial status differences.

\section{References}

Arpan, S. (2014). Saprahan Adat Budaya Melayu Sambas. Majelis Adat Budaya Melayu.

Bakar, A. Y. A. (2016). Counseling and Guidance for Malaysian Gifted Students: A Conceptual Framework. Journal for the Education of Gifted Young Scientists, 4(1), 21-29. https://doi.org/10.17478/JEGYS.2016115332

Bakar, A. Y. A., Ishak, N. M., \& Abidin, M. H. Z. (2014). The relationship between domains of empathy and leadership skills among gifted and talented students. Procedia-Social and Behavioral Sciences, 116, 765-768. https://doi.org/10.1016/j.sbspro.2014.01.294

Batubara, S. M. (2017). Kearifan Lokal dalam Budaya Daerah Kalimantan Barat (Etnis Melayu dan Dayak). Jurnal Penelitian IPTEKS, 2(1).

Buggie, S. E. (1997). Indigenous psychologies: Research and experience in cultural context-Kim, U, Berry, JW. Sage Publications Inc., 2455 Teller RD, Thousand Oaks, CA 91320. https://doi.org/10.1177/0011000009336241

Goleman, D. (1977). Emotional Intelligence-Kecerdasan Emotional. Penerbit: PT Gremdia Pustaka Utama.

Hariko, R., \& Ifdil, I. (2017). Analisis Kritik Terhadap Model Kipas; Konseling Intensif Progresif Adaptif Struktur. Jurnal Konseling Dan Pendidikan, 5(2), 109-117. https://doi.org/10.29210/120500

Hwang, K.-K. (2009). The development of indigenous counseling in contemporary Confucian communities. The Counseling Psychologist, 377), 930-943. https://doi.org/10.1177/0011000009336241

Indonesia. Undang-undang Sistem Pendidikan Nasional No. 20 tentang Penyelenggaraan Pendidikan Bagi Siswa Berkebutuhan Khusus (2003). Republic of Indonesia.

Indonesia. Peraturan Presiden No. 87 tentang Penguatan Pendidikan Karakter (2017). Republic of Indonesia.

Johnson, L. R., \& Sandhu, D. S. (2010). Treatment Planning in a Multicultural Context: Some Suggestions for Counselors and Psychotherapists. In M. M. Leach \& J. Aten (Eds.), Culture and the therapeutic process: A guide for mental health professionals (pp. 117-156). New York: Taylor \& Francis New York, NY.

Kazanjian, C. J., \& Choi, S.-J. (2016). The person over standardisation: a humanistic framework for teacher learning in diverse school-based contexts. Pedagogy, Culture \& Society, 24(2), 255-267. https://doi.org/http://dx.doi.org/10.1080/14681366.2016.1153511

King, V. T., Ibrahim, Z., \& Hassan, N. H. (2017). Borneo Studies in History, Society and Culture. Springer.

Lo, H.-T., \& Fung, K. P. (2003). Culturally competent psychotherapy. The Canadian Journal of Psychiatry, 48(3), $161-170$.

Muzayanah, U. (2017). The Role of The Islamic Education Subject and Local Tradition in Strengthening Nationalism of The Border Society (Study in Temajuk Village Sambas Regency of West Borneo). Analisa: Journal of Social Science and Religion, 2(1), 41-59.

Pedersen, P. B. (2002). The Making of A Culturally Competent Counselor. Online Readings in Psychology and Culture, 103), 4.

Pranungsari, D. (2012). Kecerdasan dan perfeksionisme pada anak gifted di kelas akselerasi. Humanitas, 71 ), 35-52.

Robinson, A., \& Clinkenbeard, P. R. (2008). History of Giftedness: Perspectives from The Past Presage Modern Scholarship. In Handbook of Giftedness in Children (pp. 13-31). Springer.

Schwean, V. L., Saklofske, D., Widdifield-Konkin, L., Parker, J. D. A., \& Kloosterman, P. (2006). Emotional Intelligence and Gifted Children. E-Journal of Applied Psychology, 2(2), pp-30.

Sugiarti, R., \& Suhariadi, F. (2015). Gambaran Kompetensi Sosial Siswa Cerdas Istimewa. In Seminar Psikologi dan Kemanusiaan (pp. 299-300).

Wahab, R. (2010). Konseling bagi anak berbakat akademik. Cakrawala Pendidikan, (1). 
Wibowo, A., \& Anjar, T. (2017). Internalisasi Nilai Kearifan Lokal (Local Wisdom) dalam Pelaksanaan Konseling Multikultural dalam Pengentasan Masalah Remaja Akibat Dampak Negatif Globalisasi. In Proceeding Seminar dan Lokakarya Nasional Bimbingan dan Konseling 2017(Vol. 1, pp. 1-9).

Zeidner, M. (2017). Tentative guidelines for the development of an ability-based emotional intelligence intervention program for gifted students. High Ability Studies, 28(1), 29-41.

Zeidner, M., \& Matthews, G. (2017). Emotional intelligence in gifted students. Gifted Education International, $33(2), 163-182$. 